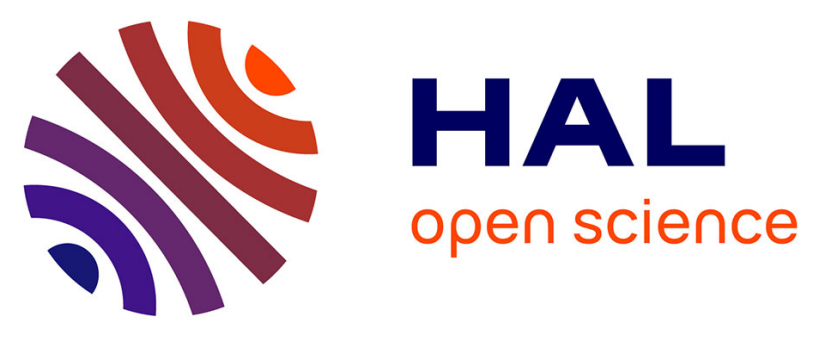

\title{
Long-term outcome of patients with non-operated prosthetic valve infective endocarditis is relapse the main issue?
}

Raphaël Lecomte, Jean-Baptiste Laine, Nahéma Issa, Matthieu Revest, Benjamin Gaborit, Paul Le Turnier, Colin Deschanvres, François Benezit, Nathalie Asseray, Thierry Le Tourneau, et al.

\section{To cite this version:}

Raphaël Lecomte, Jean-Baptiste Laine, Nahéma Issa, Matthieu Revest, Benjamin Gaborit, et al.. Long-term outcome of patients with non-operated prosthetic valve infective endocarditis is relapse the main issue?. Clinical Infectious Diseases, 2020, 71 (5), pp.1316-1319. 10.1093/cid/ciz1177 . hal02440778

\section{HAL Id: hal-02440778 \\ https://hal-univ-rennes1.archives-ouvertes.fr/hal-02440778}

Submitted on 13 Feb 2020

HAL is a multi-disciplinary open access archive for the deposit and dissemination of scientific research documents, whether they are published or not. The documents may come from teaching and research institutions in France or abroad, or from public or private research centers.
L'archive ouverte pluridisciplinaire HAL, est destinée au dépôt et à la diffusion de documents scientifiques de niveau recherche, publiés ou non, émanant des établissements d'enseignement et de recherche français ou étrangers, des laboratoires publics ou privés. 


\section{Long-term outcome of patients with non-operated prosthetic valve infective endocarditis: is relapse the main issue?}

\section{Authors:}

Raphaël LECOMTE ${ }^{1,2}$, Jean-Baptiste LAINE ${ }^{1,2}$, Nahéma ISSA ${ }^{3}$, Matthieu REVEST ${ }^{4,5}$, Benjamin GABORIT $^{1,2}$, Paul LE TURNIER ${ }^{1,2}$, Colin DESCHANVRES ${ }^{1,2}$, François BENEZIT ${ }^{4}$, Nathalie ASSERAY ${ }^{1,2}$, Thierry LE TOURNEAU ${ }^{6}$, Sabine PATTIER ${ }^{6}$, Ousama AL HABASH ${ }^{7}$, François RAFFI ${ }^{1,2}$, David BOUTOILLE $^{1,2}$, Fabrice CAMOU ${ }^{3}$

${ }^{1}$ Department of Infectious Disease, University Hospital, Nantes, France

${ }^{2}$ CIC UIC 1413 INSERM, University Hospital, Nantes, France

${ }^{3}$ Intensive Care and Infectious Disease Unit, Groupe Saint-André, University Hospital, Bordeaux, France

${ }^{4}$ Infectious Diseases and Intensive Care Unit, Rennes University Hospital, Rennes, France

${ }^{5}$ University of Rennes, CIC 1414, Inserm, BRM, UMR_1230, F-35033, Rennes, France

${ }^{6}$ Department of Cardiology, Institut du Thorax, University Hospital, Nantes, France

${ }^{7}$ Department of Thoracic and Cardiovascular Surgery, Institut du Thorax, University Hospital, Nantes, France

Corresponding author:

Raphael LECOMTE

Infectious Disease department

1 Place Alexis Ricordeau

44093 CHU NANTES

Phone: $+33(0) 240768393$

Fax: $+33(0) 240083309$

raphael.lecomte@chu-nantes.fr 


\section{Abstract}

In non-operated prosthetic valve endocarditis (PVE), long term outcome is largely unknown. We report the follow-up of 129 non-operated patients with PVE alive at discharge. At one year, the mortality rate was $24 \%$, relapses and reinfection were rare (5\% each). Enterococcal PVE was associated with a higher risk of relapse.

\section{Key-words:}

Infective endocarditis - Prosthetic valve - Relapse - Surgery 


\section{Text}

\section{INTRODUCTION}

Prosthetic valve endocarditis (PVE) is associated with a well-known high in-hospital mortality rate $(20-30 \%)[1,2]$. However, the late outcome could also represent a major concern considering that the mortality in the year following discharge ranges from 10 to $20 \%[1,3]$. Although surgery is generally considered the best option when PVE causes severe prosthetic dysfunction or heart failure, some studies indicate that early valve replacement may not always lead to better outcome in patients with PVE [1,3]. Therefore, both European (ESC) and American (IDSA) guidelines indicate that surgery for PVE should follow the general principles outlined for native valve endocarditis (NVE) $[4,5]$ and surgery was performed in only 50\% of patients with PVE in the International Collaboration on Endocarditis-Prospective Cohort Study, a similar rate as for patients with NVE [1,2].

However, there are very limited data regarding the long-term outcome in PVE patients who do not undergo surgical treatment. Considering that the affected population, microbiological epidemiology and management of IE have evolved these last years, this data should also be updated to reflect the current prognosis of these patients [1]. Because studies are rare and mainly focused on the intra-hospital prognosis of these patients [2], the rate of relapse and reinfection after medical treatment has been completed is unknown in this particular population.

The objective of our study is therefore to describe the outcomes of non-operated PVE patients focusing on the risks of relapse, reinfection and mortality. 


\section{MATERIAL AND METHODS}

An observational cohort study of definite or possible endocarditis according to the Duke criteria was designed in 3 French referent centers: Bordeaux, Nantes and Rennes University Hospitals. Adult patients with PVE confirmed by endocarditis team and managed without surgical treatment from January 2013 to December 2017 were included. Patients were excluded if they had cardiovascular implantable electronic devices (CIED), if the infection was due to obligate intracellular bacteria and if they died during the antibiotic therapy of IE (6 weeks).

Primary endpoints were infection relapse, reinfection and mortality during the year following the diagnosis of IE. Two types of recurrence are distinguishable: relapse and reinfection [4]. Relapse was defined as an additional episode of IE caused by the same microorganism with the same antibiotic susceptibility test. Reinfection was defined as an additional episode of IE caused by a different microorganism after the initial episode.

Clinical, microbiological, radiological data and surgical indications (endocarditis team decision) were obtained from a review of the patients' medical records. The patients surviving the initial treatment or their physicians were contacted one year after the diagnosis to obtain follow-up data: this included reinfection, relapse or death. The study was approved by the local ethics committee. Patients were informed of the study in accordance with French legal standards.

Data analysis was performed using the R software (v3.2.2). Estimates of frequencies and medians were calculated for categorical and continuous variables respectively. Bivariate analyses were performed using Student-t test and Fisher test with a standard significance level of $\mathrm{p}<0.05$. 


\section{RESULTS}

We screened 1,316 consecutive patients with infective endocarditis confirmed by endocarditis team (supplementary figure 1): the reasons for exclusion were NVE (861 cases), PVE with surgical treatment or death before the end of the curative treatment (219 cases), presence of a CIED (100 cases) and infection due to obligate intracellular parasite (7 cases). Finally, 129 PVE patients meeting inclusion criteria were included. Table 1 shows clinical and laboratory findings of the population. The median age was 77 years $\left(25^{\text {th }}-75^{\text {th }}\right.$ percentile, $69-84$ years $)$. The median Charlson comorbidity index was $6\left(25^{\text {th }}-75^{\text {th }}\right.$ percentile, 4-8). Organisms included streptococci (43\%), staphylococci (23\%), enterococci (18\%). Eightyfour patients had biological valves (65.1\%), 26 patients had mechanical valves (20.2\%) and 19 patients had transcatheter aortic valve replacement (14.7\%). A history of endocarditis was reported in 22 of the 129 patients $(17.1 \%)$. Embolic events occurred in 66 patients (51.2\%) mostly in the central nervous system $(25.6 \%, 33 / 129)$. Seventy-three patients $(56.6 \%)$ had no surgery despite a standard indication, 55 patients $(44 \%)$ had comorbidities or high surgical risk documented as the reason for conservative management and one patient declined surgical treatment due to personal preference.

Follow-up was achieved in all patients included. We observed 14 recurrences of PVE including 7 relapses and 7 reinfections. Four relapses were due to E. faecalis $(39,263,301$ and 353 days after the first episode), one to S. aureus (22 days), one to S. gallolyticus (208 days) and one to S. maltophilia (38 days). In bivariate analysis, enterococcal PVE was the only factor associated with a higher risk of relapse compared to other pathogens (respectively $17.4 \%$ versus $2.8 \%$, OR=7.1; CI95\% 1.1-52.1; $\mathrm{p}=.02$ ). Of the 22 patients who had a previous history of endocarditis, 4 had a recurrence $(18.2 \%)$ and 2 had a relapse $(9.1 \%)$.

In the 129 patients, the one-year mortality rate was $24 \%$ (31/129) and was lower in patients without surgical indication than in patients with indication but non-operated because of comorbidities (16.4\% vs $33.9 \%, \mathrm{p}=.02)$. In bivariate analysis, factors associated with one-year mortality were perivalvular complications $(\mathrm{p}=.002)$ and embolic lesions $(\mathrm{p}=.02)$ at baseline. Estimated overall mortality was not significantly different between patients with Staphylococcus aureus PVE versus others pathogens $(21.1 \%$ vs $24.5 \% ; \mathrm{p}=.74)$. 


\section{DISCUSSION}

The current recommendations suggest that PVE patients with no surgical treatment require close follow-up because of the risk of late events [4] but recent data are lacking. To the best of our knowledge, our series provides the most detailed description of relapse, reinfection and mortality in non-operated PVE patients.

Studies on recurrence in IE are rare and confusion between relapse and reinfection is frequent [6,7]. Some studies suggest that relapse rate in PVE may be higher than in NVE [8]. Despite the inclusion of patients expected to have a high risk of relapse in our study (PVE, no surgery, co-morbidities [4]), relapse was uncommon (5.4\%). When comparing our current results with those previously reported, we found the same relapse rate as in recent studies ranging from $5.6 \%$ to $6.5 \%[9,10]$. Interestingly, we confirm that Enterococcus is associated with a significantly higher risk of relapse. These results are consistent with the study of Iversen et al. where $6.2 \%$ of patients with enterococcal IE (NVE/PVE, operated or not) relapsed (6/97) versus $1.3 \%$ with other pathogen (4/303) [10].

In our study, the reinfection rate was relatively low possibly due to a follow-up limited to one year. In the study of Mansur et al. where 420 patients with IE were included ( 80 with PVE, mean followup of 6.1 years), $11.4 \%$ of patients had reinfection [8]. Unlike relapse risk factors, the factors of reinfection are well studied and are the same as those of first episode: presence of a mechanical valve, age, male sex, history of IE, intravenous drug use, chronic dialysis [4,8]. In a meta-analysis of 32 studies by Mihos et al. recurrence between operated and non-operated patients with PVE was not different (RR 0.38 CI95\% (0.121.23)) contrary to the 30-day mortality witch was higher among patients with non-operated PVE (25\% versus $34 \%$; RR, 0.73 ; 95\% CI, 0.64-0.82; $\mathrm{I}^{2}, 42 \%$; < <.001) [11]. However, recurrence data were only available for 58 non-operated patients out of 2,636 patients with PVE.

In our study, we found that the risk of one-year mortality is relatively low in patients who did not have any indication for surgery during the antibiotic therapy of IE (16\%). Small studies have already shown that patients with hemodynamically stable PVE could be treated with antibiotics alone [12]. We therefore provide original long-term follow-up data with a large number of patients and close monitoring of relapses to support these findings and confirm the importance of a careful selection of patients for surgery by endocarditis team.

Our studies have limitations. First, although comparable to previous studies, this study is limited by the small sample size. Second, there was no control group who underwent surgery. Third, we do not have the causes of death in our cohort. Third, streptococci were particularly frequent in our cohort and the number of drug users was particularly low: these two characteristics may limit the generalizability of the findings in other countries and continents. Last, to define relapse, the literature is inconsistent about the time between the first and second episodes with the same micro-organism with definitions ranging from 3 to 12 months $[4,7,9]$. We chose a maximal delay of one year after the initial endocarditis to avoid 
underestimating relapse rate. Furthermore, we did not use molecular methods to distinguish relapse from reinfection with a different strain of the same species.

This study adds some knowledge to our current understanding of non-operated PVE: the late mortality in IE was not the result of relapses. The mortality rate was low in PVE with absence of surgical indication and was lower than expected in patients with indication. We can therefore conclude that (i), very selected PVE could be treated safely with antibiotics alone, (ii) follow-up should focus on co-morbidities management and reinfection prevention, (iii) the risk of relapse in case of enterococcal IE should be considered for therapeutic decisions. 


\section{Acknowledgments}

Bordeaux study group: Cécile ALEXANDRINO, MD; Laurent BARANDON, MD PhD; Fabrice CAMOU, MD; Marina DIJOS, MD; Carine GREIB, MD; Nahéma ISSA, MD; Marion LAINE, MD; Irène MACHELART, MD; Olivia PEUCHANT, MD, PhD; Ghoufrane TLILI, MD; Gaëtane WIRTH, MD.

Nantes study group: Ousama AL HABASH, MD; Nathalie ASSERAY, MD; Charlotte BIRON, MD; Philippe BIZOUARN, MD; David BOUTOILLE, MD PhD; Jocelyne CAILLON, MD; Marie CHAUVEAU, MD; Caroline CUEFF, MD; Colin DESCHANVRES, MD; Guillaume DESLANDES, MD; Benjamin GABORIT, MD; Matthieu GREGOIRE, MD; Olivier GROSSI, MD; Lydie KHATCHATOURIAN, MD; Laurianne LE GLOAN, MD; Thierry LE TOURNEAU, MD PhD; Paul LE TURNIER, MD; Anne-Sophie LECOMPTE, MD; Raphaël LECOMTE, MD; Maeva LEFEBVRE, MD; Delphine MAREST, MD; Magali MICHEL, MD; Jérémie ORAIN; Sabine PATTIER, MD; Samuel PINEAU, MD; Nicolas PIRIOU, MD; François RAFFI, MD PhD; JeanChristian ROUSSEL, MD PhD; Julie ROY, MD; Thomas SENAGE, MD; Jean-Michel SERFATY, MD PhD.

Rennes study group : Pierre TATTEVIN, MD, PhD, Solène PATRAT-DELON, MD, Marion BALDEYROU, MD, François BENEZIT, MD, Marine CAILLEAU, MD, Matthieu REVEST, MD, PhD, Bernard LELONG, MD, Céline CHABANNE, MD, Erwan DONAL, MD, PhD, Erwan FLECHER, MD, PhD, Jean-Philippe VERHOYE, MD, PhD, Hervé CORBINEAU, MD, PhD, Caroline PIAU, MD, Vincent CATTOIR, PhD

\section{Conflict of Interest}

All authors: No Potential conflicts of interest. All authors have submitted the ICMJE form for Disclosure of Potential Conflicts of Interest. Conflicts that the editors consider relevant to the content of the manuscript have been disclosed.

\section{REFERENCES:}

1. Lalani T, Chu VH, Park LP, et al. In-hospital and 1-year mortality in patients undergoing early surgery for 
prosthetic valve endocarditis. JAMA Intern Med 2013; 173:1495-1504.

2. Habib G, Erba PA, Iung B, et al. Clinical presentation, aetiology and outcome of infective endocarditis. Results of the ESC-EORP EURO-ENDO (European infective endocarditis) registry: a prospective cohort study. Eur Heart J 2019; 40:3222-3232.

3. Chirouze C, Alla F, Fowler VG, et al. Impact of early valve surgery on outcome of Staphylococcus aureus prosthetic valve infective endocarditis: analysis in the International Collaboration of Endocarditis-Prospective Cohort Study. Clin Infect Dis Off Publ Infect Dis Soc Am 2015; 60:741-749.

4. Habib G, Lancellotti P, Antunes MJ, et al. 2015 ESC Guidelines for the management of infective endocarditis: The Task Force for the Management of Infective Endocarditis of the European Society of Cardiology (ESC). Endorsed by: European Association for Cardio-Thoracic Surgery (EACTS), the European Association of Nuclear Medicine (EANM). Eur Heart J 2015; 36:3075-3128.

5. Baddour LM, Wilson WR, Bayer AS, et al. Infective Endocarditis in Adults: Diagnosis, Antimicrobial Therapy, and Management of Complications: A Scientific Statement for Healthcare Professionals From the American Heart Association. Circulation 2015; 132:1435-1486.

6. Alagna L, Park LP, Nicholson BP, et al. Repeat endocarditis: analysis of risk factors based on the International Collaboration on Endocarditis - Prospective Cohort Study. Clin Microbiol Infect Off Publ Eur Soc Clin Microbiol Infect Dis 2014; 20:566-575.

7. Chu VH, Sexton DJ, Cabell CH, et al. Repeat infective endocarditis: differentiating relapse from reinfection. Clin Infect Dis Off Publ Infect Dis Soc Am 2005; 41:406-409.

8. Mansur AJ, Dal Bó CM, Fukushima JT, Issa VS, Grinberg M, Pomerantzeff PM. Relapses, recurrences, valve replacements, and mortality during the long-term follow-up after infective endocarditis. Am Heart J 2001; 141:78-86.

9. Fernández-Hidalgo N, Almirante B, Tornos P, et al. Immediate and long-term outcome of left-sided infective endocarditis. A 12-year prospective study from a contemporary cohort in a referral hospital. Clin Microbiol Infect Off Publ Eur Soc Clin Microbiol Infect Dis 2012; 18:E522-530.

10. Iversen K, Ihlemann N, Gill SU, et al. Partial Oral versus Intravenous Antibiotic Treatment of Endocarditis. N Engl J Med 2019; 380:415-424.

11. Mihos CG, Capoulade R, Yucel E, Picard MH, Santana O. Surgical Versus Medical Therapy for Prosthetic Valve Endocarditis: A Meta-Analysis of 32 Studies. Ann Thorac Surg 2017; 103:991-1004.

12. Chirouze C, Cabell CH, Fowler VG, et al. Prognostic factors in 61 cases of Staphylococcus aureus prosthetic valve infective endocarditis from the International Collaboration on Endocarditis merged database. Clin Infect Dis Off Publ Infect Dis Soc Am 2004; 38:1323-1327. 


\section{TABLE}

Table 1. Main characteristics of the 129 patients with non-operated prosthetic valve endocarditis with a focus on patients with relapse, reinfection and death ${ }^{\mathrm{a}}$.

\begin{tabular}{|c|c|c|c|c|}
\hline & $\begin{array}{c}\text { All patients } \\
n=129\end{array}$ & $\begin{array}{c}\text { Relapse } \\
\mathrm{n}=7 / 129 \\
(5.4 \%)\end{array}$ & $\begin{array}{c}\text { Reinfection } \\
n=7 / 129 \\
(5.4 \%)\end{array}$ & $\begin{array}{c}\text { Death } \\
\mathrm{n}=31 / 129 \\
(24.0 \%)\end{array}$ \\
\hline \multicolumn{5}{|l|}{ Demographics } \\
\hline Age, $\mathbf{y}$ & $77[69-84]^{\mathrm{b}}$ & $81[77.5-84.5]^{\mathrm{b}}$ & $83[65-85]^{b}$ & $78[72.5-81.5]^{b}$ \\
\hline Male sex & $102(79.1)$ & $7(100)$ & $7(100)$ & $23(74.2)$ \\
\hline \multicolumn{5}{|l|}{ Comorbidities } \\
\hline Charlson index & $6[4-8]^{b}$ & $7[5-8]^{\mathrm{b}}$ & $5[4.5-6.5]^{b}$ & $7[5-8]^{\mathrm{b}}$ \\
\hline Injection drug use & $3(2.3)$ & 0 & $1(14.3)$ & 0 \\
\hline Healthcare associated & $22(17.1)$ & $1(14.3)$ & 0 & $7(22.6)$ \\
\hline \multicolumn{5}{|l|}{ Duke classification } \\
\hline Definite IE & $109(84.5)$ & $6(85.7)$ & $4(57.1)$ & $27(87.1)$ \\
\hline \multicolumn{5}{|l|}{ Type of prosthesis } \\
\hline Mechanical & $26(20.2)$ & $2(28.6)$ & $1(14.3)$ & 7 (22.6) \\
\hline Bioprothetic $^{c}$ & $84(65.1)$ & $3(42.9)$ & $5(71.4)$ & $20(64.5)$ \\
\hline TAVR & $19(14.7)$ & $2(28.6)$ & $1(14.3)$ & $4(12.9)$ \\
\hline \multicolumn{5}{|l|}{ Valve localization } \\
\hline Aortic & $116(89.9)$ & $5(71.4)$ & $6(85.7)$ & $27(87.1)$ \\
\hline Mitral & $29(22.5)$ & $3(42.9)$ & $1(14.3)$ & $9(29.0)$ \\
\hline Multivalvular ${ }^{d}$ & $19(14.7)$ & $1(14.3)$ & 0 & $7(22.6)$ \\
\hline \multicolumn{5}{|l|}{ Echocardiography finding } \\
\hline Vegetation & $75(58.1)$ & $3(42.9)$ & $3(42.9)$ & $16(51.6)$ \\
\hline Intracardiac abscess & $29(22.5)$ & 0 & $1(14.3)$ & $13(41.9)$ \\
\hline Regurgitation & $56(43.4)$ & $4(57.1)$ & $3(42.9)$ & $15(48.4)$ \\
\hline Dehiscence & $33(25.6)$ & $3(42.9)$ & $2(28.6)$ & $10(32.3)$ \\
\hline \multicolumn{5}{|l|}{ Embolic Events } \\
\hline $\begin{array}{l}\text { Patients with at least one } \\
\text { event }\end{array}$ & $66(51.1)$ & $4(57.1)$ & $1(14.3)$ & $16(51.6)$ \\
\hline Patients with CNS events & $33(25.6)$ & $1(14.3)$ & 0 & $8(25.8)$ \\
\hline \multicolumn{5}{|l|}{ Microorganism } \\
\hline Staphylococci & $30(23.3)$ & $1(14.3)$ & 0 & $9(29.0)$ \\
\hline MSSA & $16(12.4)$ & 0 & 0 & $4(12.9)$ \\
\hline MRSA & $3(2.3)$ & $1(14.3)$ & 0 & 0 \\
\hline CoNS & $11(8.5)$ & 0 & 0 & $5(16.1)$ \\
\hline Streptococci & $56(43.4)$ & $1(14.3)$ & $2(28.6)$ & $13(41.9)$ \\
\hline S. gallolyticus & 21 & $1(14.3)$ & $1(14.3)$ & $7(22.6)$ \\
\hline Viridans streptococci & 24 & 0 & 0 & $5(16.1)$ \\
\hline Other streptococci ${ }^{\mathrm{e}}$ & 11 & 0 & $1(14.3)$ & $1(3.2)$ \\
\hline Enterococcif $^{f}$ & $23(17.8)$ & $4(57.1)$ & $3(42.9)$ & $6(19.4)$ \\
\hline Other $^{\mathrm{g}}$ & $9(7.0)$ & $1(14.3)$ & 0 & $1(3.2)$ \\
\hline Culture negative & $11(7.8)$ & 0 & $2(28.6)$ & $2(6.5)$ \\
\hline No surgery despite indication & $56(43.4)$ & $4(57.1)$ & $3(42.9)$ & $19(33.9)$ \\
\hline Follow-up & & & & \\
\hline
\end{tabular}


Data are reported as No. (\%) of patients unless otherwise indicated. Patients who relapsed and died are present in the two columns.

Abbreviations: PVE, Prosthetic valve endocarditis; IE, infective endocarditis; IQR, interquartile range; TAVR, transcatheter aortic valve replacement.

${ }^{\mathrm{a} D e a t h}$ after completion of antibiotics.

${ }^{b}$ Median (IQR).

cExcept TAVR

dAt least 2 locations.

${ }^{\mathrm{e} D e t a i l s: ~ S . ~ A g a l a c t i a e:} 6$ cases (one patient died); S. Dysgalatiae 5 cases (one patient had a reinfection).

${ }^{\mathrm{N}}$ No vancomycin-resistant enterococci

g Other microorganisms: S. maltophilia (The patient relapsed and died), E. coli, P. aeruginosa, S. marcessens, C. koseri, , K. pneumoniae Aggregatibacter aphrophilus, H. parainfluenzae, Corynebacteria sp. 